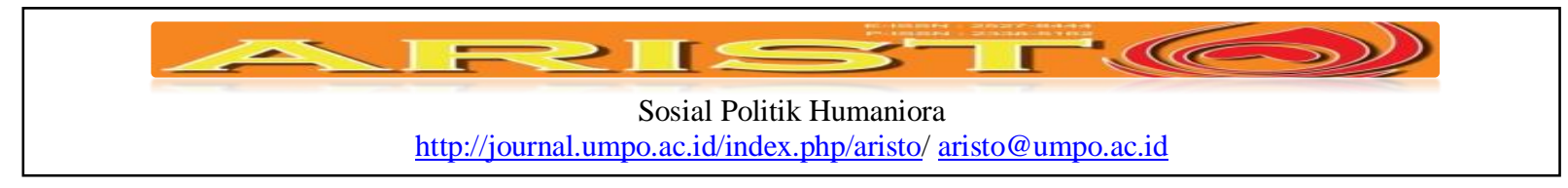

\title{
Konstruksi Masyarakat Menurut Mahatma Gandhi
}

\author{
Ketut Wisarja, I Ketut Sudarsana \\ Institut Hindu Dharma Negeri Denpasar \\ wisarja@ihdn.ac.id, iketutsudarsana@ihdn.ac.id
}

\begin{abstract}
The cotruction of society that Gandhi is trying to build is a manifestation of his religious or religious faith. Where each individual jointly runs his life activity in the life of society as a holy dharma of religion. As dharma then every individual must be able to defeat any potential greed in developing autonomization of individuality to realize mutual interests. The idealization of society that Gandhi aspires to is inseparable from the idealization of the perfection of human beings as the main core of society. The idealization of society for Gandhi is what the Indian community calls the ashram. Ashram has in common with ashrama terminology. Ashram is the ideal conception of community building as a model community. Such community prototypes contain a set of cultural roots that make up the ideological constructions of society. The cultural roots are established as living principles that must be obeyed by the ashram citizens. The estuary of all is the enforcement of the principle of brotherhood of mankind. The value of humanity that is the culmination and the key word for every form of devotion by upholding that all human beings are equal and brothers, should not be exaggerated or feel more than others. This principle of 'all brothers' is the moral principle in Gandhi idealized society. The implications of Gandhi's thought increasingly find a point of relevance to forming civil society in Indonesia.
\end{abstract}

Keyword: Community Construction, Nonviolence, and Ashram.

\begin{abstract}
Abstrak
Konstruksi masyarakat yang hendak dibangun Gandhi merupakan manifestasi dari ajaran religiusitas atau keyakinan keagamaannya. Dimana setiap individu bersama-sama menjalankan aktivitas hidupnya dalam kehidupan masyarakat sebagai suatu dharma suci agama. Sebagai dharma maka setiap individu harus dapat mengalahkan segala potensi keserakahan dalam mengembangkan otonomisasi individualitasnya untuk mewujudkan kepentingan bersama.Idealisasi masyarakat yang dicita-citakan Gandhi tidak terlepas dari idealisasi kesempurnaan dari manusianya sebagai inti pokok penyusun masyarakat. Idealisasi masyarakat bagi Gandhi adalah apa yang oleh masyarakat India disebut ashram. Ashrammempunyai kesamaan dengan terminologi ashrama. Ashram adalah konsepsi ideal tentang bangunan masyarakat sebagai komunitas teladan.Prototype masyarakat seperti itu memuat seperangkat akar kultural yang membentuk konstruksi masyarakat yang dicita-citakan. Akar kultural tersebut ditegakkan sebagai prinsip-prinsip hidup yang harus ditaati oleh warga ashram. Muara dari semua itu adalah penegakan prinsip persaudaraan umat manusia. Nilai kemanusiaan yang menjadi titik puncak dan kata kunci bagi setiap bentuk pengabdiandengan menjunjung tinggi bahwa semua manusia adalah sama dan bersaudara, tidak boleh ada yang dilebihkan atau merasa lebih dibandingkan dengan yang lainnya. Prinsip 'semua manusia bersaudara' inilah yang menjadi prinsip moral dalam masyarakat yang diidealisasikan Gandhi. Implikasi pemikiran Gandhi tersebut semakin menemukan titik relevansinya untuk membentuk masyarakat sipil (civil society) di Indonesia.
\end{abstract}

Keyword: Konstruksi Masyarakat, Tanpa kekerasan, dan Ashram.

\begin{tabular}{|ll|}
\hline Submite & $:$ 20 Desember 2017 \\
Review & $:$ 10 Januari 2018 \\
Accepted & $:$ 25 Juni 2018 \\
Surel Corespondensi & $:$ jovani.audra@ gmail.com \\
\hline
\end{tabular}

Ketut Wisarja, I Ketut Sudarsana, Konstruksi Masyarakat Menurut Mahatma Gandhi /01/ Vol. 6. No.2. Tahun 2018 


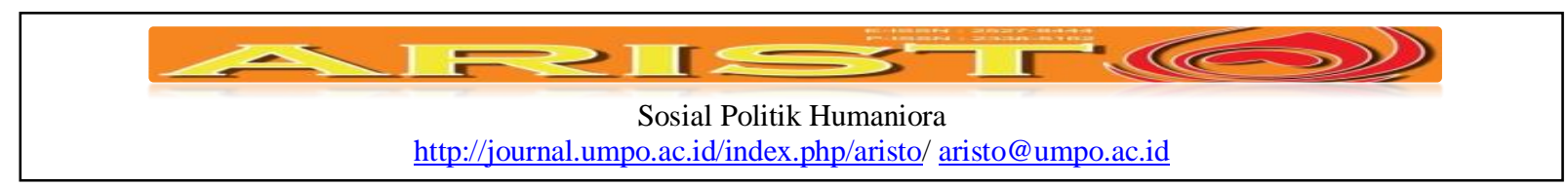

\section{Pendahuluan}

Pada dasarnya Mahatma Gandhi secara eksplisit tidak pernah memberikan batasan dan pemahaman secara sistematis mengenai masyarakat. Pemahamannya tentang masyarakat selalu terintegrasi ke dalam seluruh gagasan-gagasan besarnya tentang perlunya tatanan dalam masyarakat yang harmoni dan terhindar dari berbagai bentuk konfliktual. Namun demikian, sebagai seorang yang sangat konsisten memegang pendiriannya dan keteguhannya untuk membangun suatu komunitas yang mengedepankan harmoni sosial, maka Gandhi selalu berusaha menampilkan suatu konsepsi tentang konstruksi masyarakat, bukan pengertian tentang masyarakat.

Gagasan Gandhi tentang masyarakat tidak bisa dilepaskan dari gagasan pokoknya tentang prinsip-prinsip pola relasi antar manusia untuk hidup berdampingan secara damai, toleran dan jauh dari perilaku kekerasan. Pola relasi antar manusia yang kemudian berada dalam suatu tempat (wilayah) adalah jaminan pertama dan utama yang membentuk masyarakat. (Gandhi, 1988). Artinya, masyarakat adalah suatu komunitas yang terjadi dan terbentuk dari proses relasi antar manusia yang menduduki suatu wilayah tertentu.

Hubungan antar manusia tersebut tidaklah dipahami dalam proses secara individual, dimana manusia dianggap sebagai subjek otonom, sebagaimana dipahami oleh konstruksi masyarakat modern, melainkan manusia adalah mahluk yang beragama dengan kemampuannya untuk menjadi otonom, tetapi dengan tetap menghargai hubungannya dengan kehidupan manusia yang lain. Gandhi menganggap bahwa manusia tidak dapat menjadi otonom ketika tidak membangun suatu bentuk relasi dengan manusia lainnya. Individualitas menjadi tidak berarti ketika manusia hanya hadir di dunia dalam kesendiriannya tanpa manusia yang lain. (Gandhi, 1988).

Manusia sebagai mahluk otonom selalu berusaha sekuat tenaga untuk membangun hubungan baik dengan sesama. Prinsip inilah yang menjadi suatu pendasaran tentang konsepsi masyarakat bagi Gandhi, bahwa masyarakat terbentuk karena kehadiran manusia sebagai mahluk otonom dan berkorelasi. Faktor berkorelasi tersebut memberikan suatu ikhtiar bagi manusia untuk tidak memusnahkan manusia lainnya dan menghindarkan diri dari perilaku kekerasan.

Konsepsi dasar Gandhi tentang manusia inilah menjadi titik tolak mengenai pemahamannya tentang masyarakat. Gandhi menganggap bahwa masyarakat yang sempurna tidak bisa dilepaskan dari suatu keadaan manusianya yang memiliki kesempurnaan pula. Begitu 


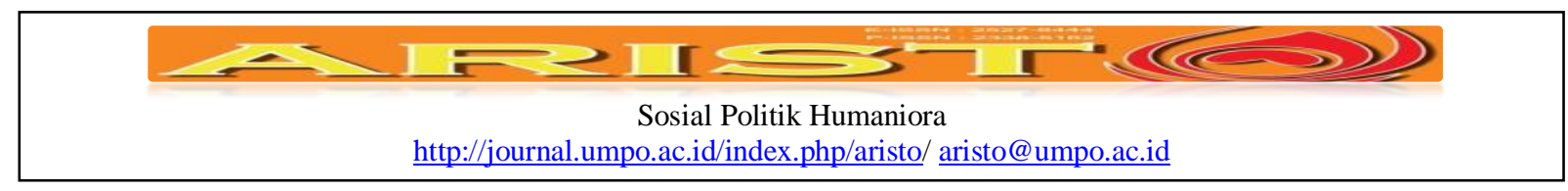

pula sebaliknya, manusia yang jahat juga berakibat bagi bangunan masyarakat yang menjadi tempat dimana para individu tersebut mengembangkan kehidupannya. Bagi Gandhi manusia yang sempurna adalah pribadi yang satyagrahi, yaitu orang yang mampu mengatasi kekuatankekuatan jahat yang dilakukan dengan sikap ahimsa dan pemurnian diri yang mencakup sikap lepas bebas terhadap harta milik dan bebas terhadap kelezatan dan kenikmatan melalui pengekangan diri, puasa, dan brahmacharya. Kesempurnaan manusia yang demikian pada akhirnya akan berhubungan dengan kondisi masyarakat yang dibentuknya. (Wegig, 1986)

Konsekuensi logisnya, kebaikan dan kesempurnaan suatu masyarakat sangat terpengaruh oleh kehidupan manusia di dalamnya. Karena manusia adalah penyusun bagi bangunan sebuah masarakat (Gandhi, 1988). Artinya, baik buruknya suatu masyarakat dipengaruhi oleh keadaan dari para penyusunnya, yaitu perilaku manusianya. Tidak akan ada gunanya mengidealisasikan suatu komunitas yang sempurna, ketika tidak disertai dengan suatu keteguhan hati untuk menjadikan manusia secara sempurna pula. Meski manusia sempurna secara individu, pada akhirnya ia juga akan menyempurnakan dirinya secara sosial.

Konstruksi pemahaman Gandhi yang demikian seolah mengindikasikan bahwa ia adalah seorang penganut paham individualisme yang mementingkan aspek otonomisasi manusia. Padahal Gandhi sesungguhnya adalah orang yang sangat menghargai manusia sebagai subjek otonom disatu sisi dan juga menekankan aspek sosialitas manusia disisi lainnya. Bagi Gandhi, otonomisasi manusia sebagai mahluk individu tidak mempunyai makna apa-apa manakala tidak dikembangkan dalam konteks sosialitas manusia. Kebebasan manusia sebagai mahluk otonom, tidaklah boleh melanggar kepatuhan sosial. Artinya, otonomisasi manusia secara individual tetap dihargai dalam konteks hubungannya dengan orang lain. Manusia dalam sosialitasnya tidak hidup sendirian, melainkan ia menjadi bermakna nilai kemanusiaannya ketika hidup bersama dan menghormati orang lain yang juga memiliki otonomisasinya sendiri.

\section{Metode}

Penelitian ini menggunakan metode penelitian kualitatif, dimana lebih menekankan pada proses dan makna yang akan dikaji secara utuh, statis dan konkrit yang berlandaskan pada filsafat sosial. Pada kondisi yang alamiah dari munculnya berbagai perubahan paradigma dalam fakta kehidupan sosial, realita atau fenomena yang terjadi di masyarakat tersebut dapat diklasifikasikan, realita tetap, konkrit, teramati, terukur, dan dilakukan hubungan gejala yang 


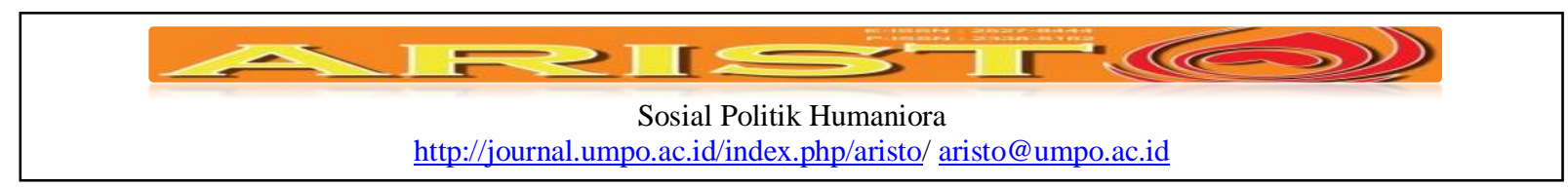

bersifat sebab akibat. Dalam paradigma perubahan tersebut dipandang sebagai suatu yang naturalistik karena penelitiannya dilakukan pada kondisi yang alamiah, holistik, kompleks, dinamis, dan penuh makna yang sering disebut paradigma positivisme yang mengembangkan jenis penelitian kualitatif.

Pendekatan yang dipergunakan adalah pendekatan kualitatif, dengan instrumen yang dipergunakan adalah berbagai alat bantu pengumpulan data, seperti pedoman wawancara, pedoman observasi, alat-alat perekam dan sebagainya. Adapun metode pengumpulan data yang digunakan dalam penelitian ini diantaranya observasi, wawancara, dokumentasi, dan studi kepustakaan. Selanjutnya data yang diperoleh dianalisis dengan langkah-langkah seperti; (1) Reduksi data, (2) Klasifikasi data, (3) Interpretasi data, dan (4) Penarikan kesimpulan.

\section{Hasil danPembahasan}

\section{Bangunan Masyarakat yang Diidealisasikan Mahatma Gandhi}

Hidup bersama dalam masyarakat pada dasarnya menunjukkan dimensi keagamaan yang mendalam. Hal ini karena bagi Gandhi bahwa hidup bermasyarakat merupakan dharma; pengabdian dari setiap manusia. Menurut Gandhi, dunia kemasyarakatan tidaklah sekuler, dunia kemasyarakatan adalah suci. Implikasi logisnya, setiap orang harus terlibat di dalamnya, ini berarti setiap orang juga harus terlibat di dalam dharma suci sebagai manusia. Penyerahan diri pada tuntutan-tuntutan dharma tersebut pada dasarnya merupakan wujud penyerahan murni serta bersahaja kepada Tuhan dan kehendak-Nya, yang dimanifestasikan ditengah-tengah rakyat. (Thomas Merton, 1992)

Dengan demikian, konsepsi masyarakat yang hendak dibangun oleh Gandhi merupakan manifestasi dari ajaran religiusitas atau keyakinan keagamaannya. Dimana setiap individu bersama-sama menjalankan aktivitas hidupnya dalam kehidupan masyarakat sebagai suatu dharma suci agama. Sebagai dharma maka setiap individu harus dapat mengalahkan segala potensi keserakahan dalam mengembangkan otonomisasi individualitasnya untuk mewujudkan kepentingan bersama.

Dharma telah menjadi spirit utama bagi Gandhi untuk memberikan suatu pemahamannya tentang hubungan timbal balik dalam masyarakat dari setiap individu. Hubungan timbal balik merupakan keniscayaan sejarah dalam peradaban kemanusiaan. Tiada kehidupan di dunia ini yang saling terlepas satu sama lain, melainkan semuanya terkait secara 


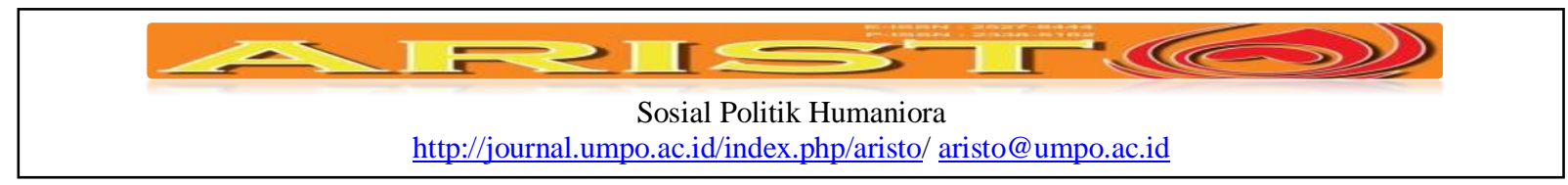

timbal balik. Sebagaimana dikatakan Gandhi, yakni; "Keterkaitan dan ketergantungan yang timbal balik seharusnya dijadikan cita-cita umat manusia, selain dari hasrat untuk berswasembada. Manusia adalah mahluk sosial. Tanpa keterkaitan dengan masyarakat, tidak mungkin akan disadarinya persatuan dengan seluruh alam semesta dan tidak mungkin ditindasnya nafsu kepentingan sendiri. Keterkaitan timbal balik dengan masyarakat memungkinkan dia menguji imannya pada batu ujian kenyataan, seandainya seseorang telah diberi kedudukan ataupun bila dia mampu mencapai kedudukannya yang mengakibatkan dia lepas dari segala keterkaitan dengan sesama mahluk, dia pasti akan menjadi bangga dan angkuh.... Ketergatungan pada masyarakat membuat dirinya sadar akan sifat umat manusia". (Gandhi.1988)

Keterkaitan individu dengan masyarakat, dengan demikian seperti hukum sejarah atau hukum alam yang tidak boleh dilepaskan. Tanpa keterkaitan, manusia hanya menjadi seonggok subjek otonom yang tidak memiliki nilai atau jauh dari sikap dharma. Hidup dalam Masyarakat adalah bagian terpenting dari dharma sebagai manusia. Lebih jauh Gandhi menguraikan; setiap pengabdian dalam masyarakat, tidaklah mungkin saling melepaskan diri dari bagian-bagiannya. Kewajiban seseorang kepada dirinya sendiri, kepada keluarganya, kepada bangsanya dan kepada seluruh dunia, misalnya; mutlak saling berkaitan. Tidak mungkin seseorang berjasa kepada tanah airnya dengan merugikan diri sendiri atau keuarganya. Demikian pula tidak mungkin orang berjasa kepada tanah airnya dengan cara merugikan dunia luar. Sehingga, wujud dari pengabdian seseorang kepada masyarakat adalah membangun secara bersama-sama kepentingannya masing-masing dengan tetap mengedepankan kepentingan bersama. Artinya, masyarakat yang dikembangkan adalah komunitas yang saling terkait dan tergantung antar setiap individu untuk bersama mewujudkan kehidupan yang lebih baik. Dalam hal ini individu juga perlu dikembangkan potensi otonomisasinya, tetapi tetap dalam kerangka sosialitas manusia.

\section{Ashram sebagai Model Idealisasi Masyarakat}

Sebagai wujud tidak adanya konsepsi secara sistematis dari Gandhi tentang arti dan makna masyarakat, ia lebih mementingkan suatu wujud ideal dari masyarakat tersebut. Idealisasi masyarakat yang hendak dibangun dan dicita-citakan Gandhi pada dasarnya juga tidak terlepas dengan idealisasi kesempurnaan dari manusianya sebagai inti pokok penyusun 


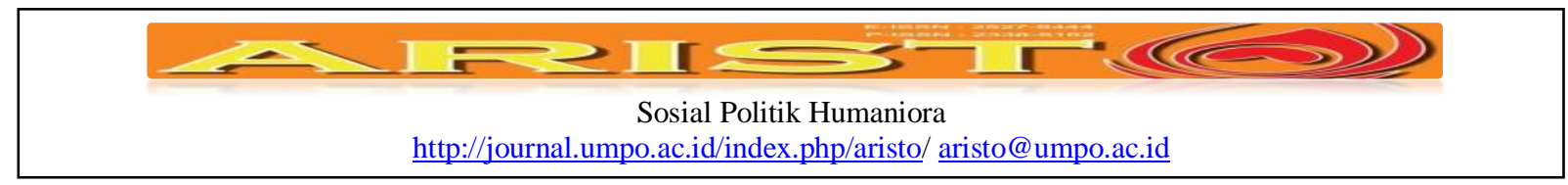

masyarakat. Idealisasi masyarakat bagi Gandhi adalah apa yang oleh masyarakat India disebut ashram, yang mempunyai kesamaan dengan terminologi ashrama. Ashram disadari adalah konsepsi ideal tentang bangunan masyarakat yang hendak dicita-citakan oleh Gandhi sebagai komunitas teladan.

Wakefield menjelaskan bahwa pengertian ashram asal mulanya berarti suatu pemukiman dihutan, dimana seseorang menarik diri dari sisa kehidupannya setelah memenuhi tugas-tugas orang tua atau rumah tangganya, untuk mencari kedamaian dan konsentrasi rohaniah yang kuat tentang suatu pandangan dan kesatuan realitas yang merupakan sumber dari segala yang berwujud. Dalam perspektif ini, ashram merupakan lembaga keagamaan, utamanya yang melembaga dalam masyarakat Hindu di India. Ashram biasanya didirikan oleh pemimpin spiritual keagamaan yang menghabiskan kehidupannya untuk men-dharma-kan baktinya kepada Tuhan setelah menjalani proses-proses kehidupan duniawi. Sebut saja misalnya, Gopal Khrisna Gokhale dengan lembaganya 'The Servants of India Society', sastrawan Rabindranat Tagore dengan ashramSantiniketan-nya; dan Swami Sradananda yang mendirikan Gurukula (Andrews, 1949).

Gandhi adalah seorang pemimpin spiritual yang juga mencita-citakan terwujudnya suatu ashram untuk mengamalkan dan meneruskan ajaran-ajarannya.Ashram yang dicitacitakan oleh Gandhi pada dasarnya dilatarbelakangi oleh realitas kesengsaraan hidup masyarakat India di Afrika Selatan pada paruh tahun 1900-an yang hidup di bawah ketertindasan dan kesewenang-wenangan penguasa saat itu. Dilatarbelakangi oleh situasi tersebut, Gandhi memulai kehidupannya dengan menekankan pada kesederhanaan. Suatu sikap hidup yang merepresentasikan kehidupan seorang grehasta. Sikap hidup yang demikian merupakan upaya untuk mendasari munculnya gerakan satyagraha, yaitu suatu gerakan yang menggunakan prisip-prinsip non-violence (tanpa kekerasan).

Keinginan untuk membangun komunitas yang mengedepankan gerakan satyagraha tersebut, Gandhi mengawalinya dengan membangun 'Phonix Settlement' atau Perkampungan Phonix, yang letaknya 12 mil dari Durban, Afrika Selatan. Perkampungan Phonix yang didirikan oleh Gandhi pada awalnya juga diilhami dari tulisan Unto This Last karya Ruskin; "Tahun 1904 pada saat saya membaca bukunya Ruskin, Unto This Last, yang amat terkesan pada saya. Saya memutuskan untuk memindahkan 'Indian Opinion' dan membuka tanah baru 


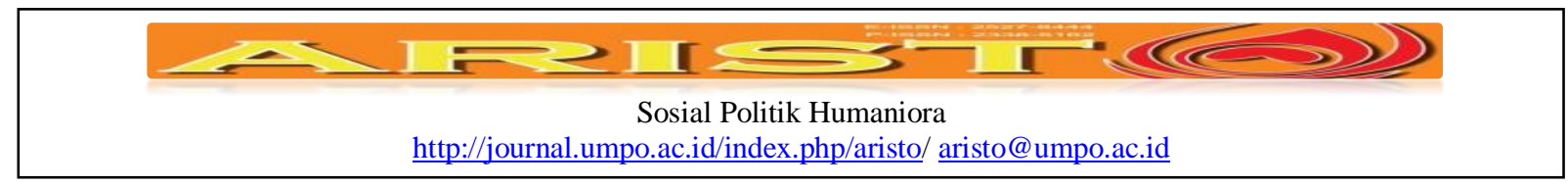

dengan pekerja-pekerja sebagai suatu keluarga besar. Maka saya membeli tanah seluas 100 acree dan mendirikan Phonix Settlement" (Gandhi, 1981)

Keinginan Gandhi untuk mendirikan komunitas masyarakat India yang teladan dengan perilaku dan kehidupan yang mengamalkan ajaran spiritualnya adalah bukti awal bahwa ia memiliki sejumlah konsepsi tentang masyarakat yang diidealisasikannya.

Berdasarkan pada keyakinan keagamaannya yang mendalam, Gandhi mendirikan 'Perkampungan Phonix' tersebut. Sehingga, banyak pihak menyebut bahwa dasar Perkampungan Phonik adalah agama yang bertujuan melatih kemurnian badan dan pikiran serta mencita-citakan kedudukan ekonomi yang sama. Dalam perkampungan tersebut, setiap warga diharuskan melakukan kerja secara jasmani untuk memenuhi kebutuhan diri sendiri, dan mendapatkan upah yang sama untuk nafkahnya. Perkampungan Phonix menjadi masyarakat teladan yang dicita-citakan Gandhi untuk melakukan brahmacharya (kebersihan lahir dan batin). Brahmacharya seolah menjadi sine qua non, kondisi wajib bagi setiap warga untuk melaksanakan dharma-nya kepada kehidupan.

Pada perkembangan selanjutnya bersama Hermaun Kallen seorang sahabatnya di Afrika Selatan, Gandhi mendirikan sebuah ashram yang dinamakan 'Tolstoy Farm' di atas tanah seluas 1100 acree di Lawely dekat Johannesburg. Penggunaan istilah Tolstoy mengindikasikan kuatnya pengaruh Tolstoy pada diri Gandhi dan berusaha untuk mengamalkan pemikirannya. Dalam Tolstoy Farm ini, semua didasarkan pada keyakinan spiritual Gandhi yang mengharuskan warganya mengamalkan ahimsa dan silibasi. Suatu prinsip hidup yang harus ditaati oleh setiap individu yang hidup dalam ashram tersebut.

Doktrin ahimsa mengharuskan seseorang mencintai kehidupan, baik sesamanya maupun kepada mahluk lainnya dengan tanpa melukai atau menyakiti. Sedangkan doktrin silibasi diwujudkan dalam bentuk pemisahan tempat tinggal antara laki-laki dan wanita, termasuk kepada mereka yang sudah menikah-pun harus mentaati prinsip ini. Doktrin ini seolah mencerminkan suatu ajaran dari para sosialisme utopis klasik yang berusaha mencitacitakan suatu komunitas teladan yang hidup dalam sebuah tempat dengan aturan yang sangat ketat. Plato misalnya, pernah mengintrodusir suatu komunitas teladan dimana para pemimpin dalam komunitas tersebut dilarang memiliki harta benda sekaligus tidak diperbolehkan untuk menikah, karena bagi Plato kecintaan pada harta benda dan keluarga adalah awal dari perilaku kerusakan, termasuk korupsi dan keserakahan. 


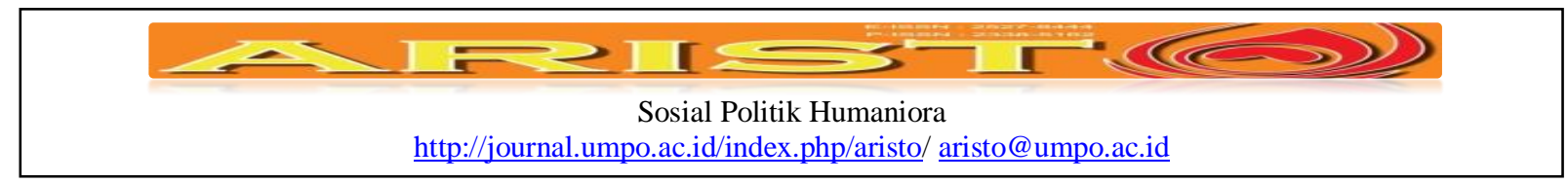

Komunitas ideal dalam ashram yang dibentuk oleh Gandhi tersebut seolaholahmengindikasikan suatu sikapnya untuk merealisasikan konsep masyarakat yang sempurna. Untuk merealisasikan konsep tersebut, maka Gandhi tidak hanya berbicara pada tataran ide, melainkan menjadikannya dalam bentuk praksis. Setiap individu dalam ashram harus mengamalkan dan mentaati ajaran spiritual yang dikemukakan dan diyakini oleh Gandhi. Sehingga melalui pelaksanaan ajaran spiritual tersebut diharapkan terjadi kesamaan kehidupan dalam setiap warga tanpa terkecuali. Artinya, setiap warga yang awalnya berlatarbelakang sosial yang berbeda, tetapi ketika hidup dalam ashram, maka semuanya harus menjadi satu; yaitu satu keluarga besar tanpa ada diskriminasi.

Sebagaimana dijelaskan di atas, dalam ashram tidak hanya terdiri dari satu komunitas yang sama, melainkan berasal dari berbagai ragam komunitas dengan identitasnya masingmasing. Dalam Tolstoy Farm, para warganya tidak saja terdiri dari orang India, melainkan juga orang Eropa yang berlainan agama. Terminologi ashramsendiri pada dasarnya menunjukkan suatu kebersamaan dan satu kesatuan tanpa ada perbedaan. Menjadi warga dalam ashram dengan sendirinya menjadi satu keluarga Setiap warga diwajibkan melakukan kerja secara bersama, tidak ada yang menjadi pembantu, semua pekerjaan harus dikerjakan sendiri tanpa menyuruh orang lain yang menjadikan kedudukan orang lain sub-ordinat. (Gandhi, 1978).

Prinsip hidup yang dicoba dikembangkan dalam ashram tersebut adalah kesederhanaan. Meskipun demikian, dalam komunitas tersebut tetap dijalankan latihan-latihan keagamaan dan moral. Bagi Gandhi moral merupakan keharusan bagi orang yang menjunjung dan membela kebenaran, karena moralitas adalah dasar bagi segala sesuatu, dan kebenaran merupakan inti moralitas. Dengan demikian, ashram dengan bentuk dan nama yang berbedapun pada dasarnya selalu disemangati oleh penekanan hidup sederhana serta persiapanpersiapan pada warganya untuk menjadi Satyagrahi, termasuk ketika Gandhi memindahkan lokasi ashram ke India pada tahun 1912. (Gandhi, 1978).

Komunitas teladan atau ashram yang didirikan Gandhi di India diberi nama Satyagraha. Pemberian nama ini dilandasi oleh suatu keinginan untuk menyesuaikan diri dengan tujuan dan cara pengabdiannya, dan kegiatan pokok dalam ashram adalah menenun pakaian sebagai upaya penghargaan terhadap kerja badani yang menekankan pada kesederhanaan. Menariknya, dalam kehidupan sehari-hari, para penghuni diwajibkan untuk 


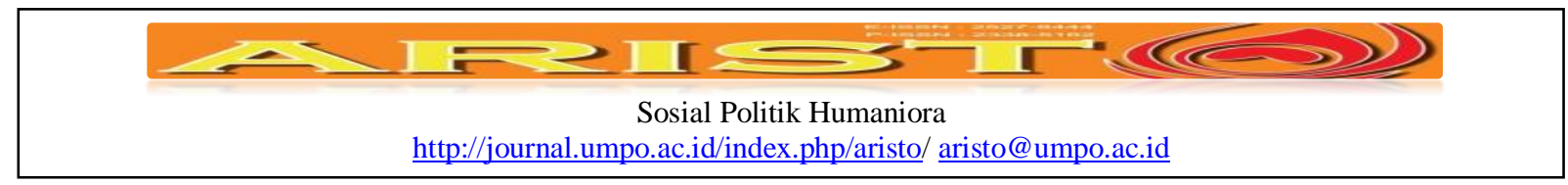

menolong diri sendiri. Artinya, setiap warga baik laki-laki maupun wanita diharuskan berkarya pangan atau bekerja untuk hidupnya. Kewajiban ini berlaku bagi yang sehat maupun yang sakit, dan orang tua dibantu dalam pelayanan. (Gandhi, 1978).

Dalam ashram diberikan sejumlah aturan berdasarkan kesepakatan bersama yang tidak boleh dilanggar. Kesepakatan bersama ini mengindikasikan bentuk-bentuk sosialisme utopis, karena di dalamnya juga menunjuk pada suatu kenyataan kepemilikan dan tanggungjawab bersama. Setiap pekerjaan harus dijalankan bersama, tidak diperkenankan terjadinya proses pelibatan orang luar ashram yang membantu bekerja, termasuk di dalamnya adalah program pokok pemintalan benang sebagai upaya untuk membantu bangsa dan tanah air yang saat itu dilanda kelaparan. Bagi Gandhi setiap warga ashram memiliki kewajiban untuk berkorban demi bangsa dan tanah air. Oleh karena itu, ketika rakyat India menghadapi problem kelaparan akibat penghasilan utamanya dihancurkan oleh Kolonial Inggris, maka serentetan program kerja berkaitan dengan pemulihan kerja pokok rakyat mulai digiatkan, misalnya; penanaman kapas, memberus, memintal, menenun kain, memisahkan biji kapas, perbengkelan untuk membuat jantera, mencelup sekaligus mencetaknya, dilakukan oleh warga ashram. (Gandhi, 1981).

Komunitas teladan dalam ashram ini menunjukkan watak kemandirian yang sangat mengagumkan, sebab selain menunjukkan kemandirian dalam usaha memintal, juga dijalankan usaha pemerahan susu dan penyamakan kulit sapi untuk dijadikan sandal dan sepatu. Penyamakan kulit harus diambil dari kulit sapi yang sudah mati, karena dalam tradisi Hindu terdapat larangan membunuh sapi sebagai binatang yang dilindungi. Upaya-upaya tersebut mengandung makna yang mendalam bagi tumbuhnya swasembada dan swadaya dari warga untuk tidak tergantung kepada orang lain, apalagi terhadap negara koloni.

Sebagai suatu bentuk masyarakat yang dicita-citakan, Gandhi juga memberikan suatu bentuk pengajaran bagi warga agar memiliki kemampuan intelektualitas, seperti; membaca dan menulis. Dalam hal ini Gandhi menjelaskan; "Jika dikehendaki dan memungkinkan, ashram patut memberikan kepada para pekerja waktu yang lebih lapang untuk membaca dan menulis, dan juga pantas kalau warga yang buta huruf diberikan seorang guru untuk membantu mereka dalam pekerjaannya. Namun waktu untuk membaca dan semacamnya tidak dapat disisihkan dengan pengorbanan kegiatan-kegiatan yang sudah ada di ashram sekarang ini”. (Gandhi, 1981). 


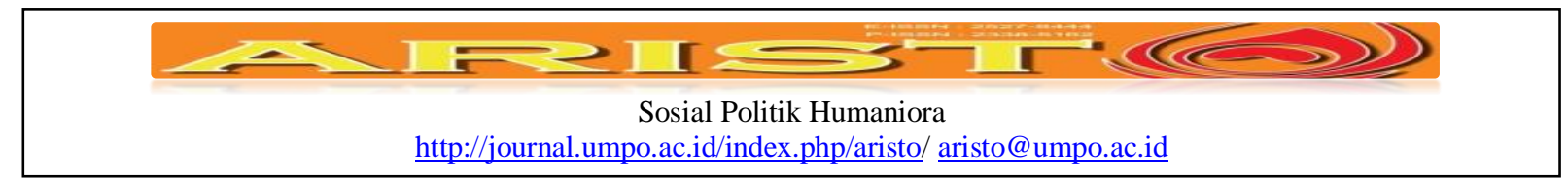

Pemahaman ini semakin memberikan bukti bahwa dalam ashram, kerja menjadi sesuatu yang sangat penting. Orientasi pendidikan ashram diarahkan pada kesejahteraan bangsa. Setiap bentuk pendidikan, baik spiritual, intelektual dan perkembangan badan harus dapat dikembangkan bersama. Keberhasilan tersebut hanya dapat dicapai melalui proses perangsangan untuk menciptakan kerajinan sebagai suatu karya nyata, sedangkan teori hanya diberikan menurut keperluannya saja.

Realitas kehidupan dalam ashram menunjukkan suatu sisi kebersamaan dalam setiap warga. Semua warga mempunyai hak dan kewajiban yang sama serta proses pentaatan terhadap prinsip-prinsip yang dikembangkan dalam ashram yang tidak pandang status sosial dan latar belakang agama. Hal ini menunjukkan suatu bentuk masyarakat yang mempunyai orientasi kehidupan yang sama berdasarkan nilai-nilai spiritual yang sama pula yang dijunjung tinggi sebagai kebaikan bersama.

Proses kehidupan sosial dalam ashram adalah pencerminan sikap hidup Gandhi yang memiliki satu komitmen bahwa semua manusia adalah bersaudara. Tidak ada musuh dan tidak ada lawan, yang ada adalah kawan. Sehingga, prinsip ini melatarbelakangi kehidupan warga di ashram untuk menjauhkan diri dari perilaku yang merusak dan merugikan diri sendiri dan orang lain.

Dalam kehidupan ashram yang harus dijaga adalah bagaimana membangun ketaatan warganya terhadap setiap peraturan yang sudah disepakati bersama. Ciri yang membedakan antara penghuni ashram sebagai komunitas teladan dengan masyarakat lainnya adalah keteguhan mereka dalam menjaga dan mengemban peraturan. Selama ini realitas membuktikan bahwa ketidaktaatan terhadap aturan bersama merupakan awal dari kehancuran dan rusaknya tatanan dalam masyarakat.

Sebagaimana disebutkan di atas, jalannya kehidupan di ashram senantiasa diatur oleh peraturan-peraturan yang disepakati bersama. Pandangan Gandhi terhadap peraturan tersebut adalah sebagai sumpah yang harus ditaati, karena aturan tersebut akan menghantar pada tercapainya cita-cita dan sekaligus sebagai penangkal kendala yang muncul dan yang menghambat terealisasinya cita-cita tersebut. Bagi Gandhi, sumpah memiliki peranan yang penting dalam keteguhan menjaga komitmen bersama. Sebagaimana dikatakan Gandhi (1951: 11) "Bersumpah bukan suatu tanda kelemahan, tetapi suatu kekuatan. Untuk setiap pengorbanan, seseorang harus melakukan sumpah. Ia akan menjadi suatu benteng kekuatan. 


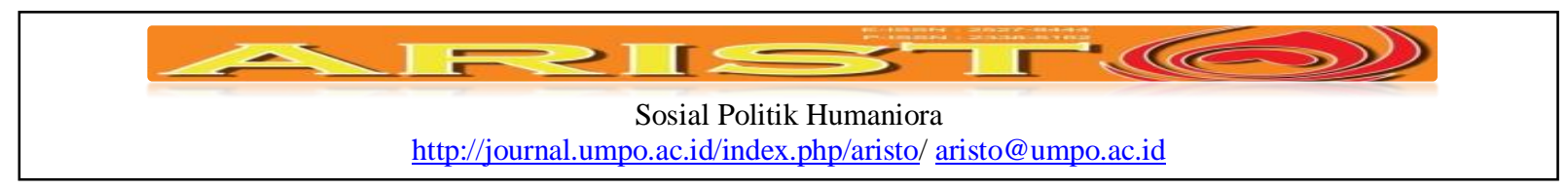

Seseorang yang mengatakan akan melakukan 'sejauh mungkin', berarti akan menyingkapkan kegagahan atau kelemahan".

Peranan sumpah bagi warga ashram adalah sebagai kekuatan untuk meneguhkan kesadaran untuk menaati peraturan yang ada. Tanpa ikatan tersebut dikhawatirkan setiap warga akan hidup sekehendak hatinya, dan itu sangat berbahaya bagi pencapaian cita-cita yang terdapat dalam ashram.

\section{Moralitas Masyarakat Tanpa Kekerasan}

Konsepsi masyarakat menurut Gandhi di atas memuat seperangkat akar kultural yang membentuk konstruksi masyarakat yang dicita-citakan. Akar kultural tersebut diwujudkan dalam pendirian ashram yang didalamnya terdapat prinsip-prinsip hidup yang semestinya harus ditaati oleh warganya. Muara dari ketaatan terhadap berbagai bentuk prinsip tersebut adalah bahwa Gandhi sepakat untuk memberikan suatu argumen tentang prinsip persaudaraan umat manusia. Nilai kemanusiaan yang menjadi titik puncak bagi setiap bentuk pengabdian menjadi kata kunci untuk memberikan suatu penilaian bahwa setiap manusia adalah sama dan bersaudara, tidak boleh ada yang dilebihkan atau merasa lebih dibandingkan dengan yang lainnya. Prinsip 'semua manusia bersaudara' inilah yang menjadi prinsip moral dalam masyarakat yang diidealisasikan (Gandhi. 1959)

Prinsip-prinsip yang terdapat dalam ashram yang didirikan Gandhi tersebut di atas merupakan suatu bentuk penghargaan terhadap nilai-nilai kemanusiaan sebagai bentuk pengabdian tertinggi. Kemanusiaan adalah suatu representasi atas prinsip bahwa semua manusia bersaudara. Tanpa peneguhan pada prinsip ini maka interaksi sosial dalam masyarakat hanya memunculkan sikap saling permusuhan, saling membenci dan saling menyakiti yang ujung-ujungnya adalah dibiarkannya perilaku kekerasan dalam masyarakat. Kekerasan bagi Gandhi adalah bentuk pengingkaran atas kemanusiaan. Kekerasan adalah wujud bahwa antar manusia dalam sebuah interaksi sosial tidak menjalankan suatu keyakinan bahwa semua manusia adalah bersaudara (Thomas Merton, 1992)

Persepsi Gandhi bahwa semua manusia bersaudara tidak bisa dilepaskan dari pengertiannya tentang manusia. Sebagaimana dijelaskan di atas, manusia tidak akan menemukan dirinya sendiri, tanpa terlibat dalam kebutuhan besar, yaitu sosialitas. Manusia memang mahluk otonom, tetapi otonom yang berkorelasi Artinya, tanpa korelasi, otonom 


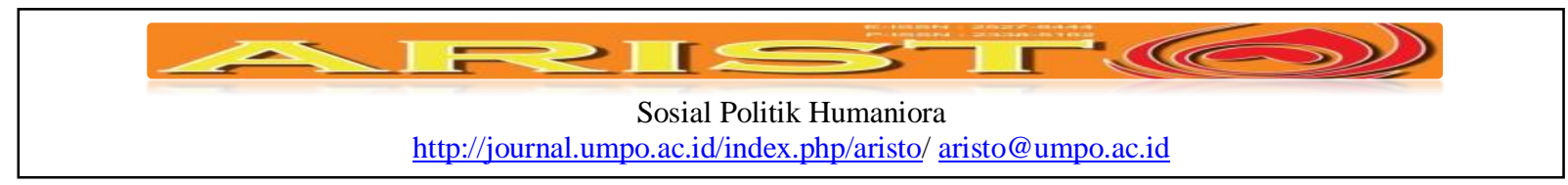

tidak bisa ditentukan. Itulah sebabnya, Gandhi berpegang teguh pada pemahaman untuk mengajarkan kepada setiap orang agar menghargai orang lain sebagai manusia. Manusia dengan nilai kemanusiaannya harus menjadi landasan dalam setiap bentuk pergaulan hidup dalam sosialitas. (Gandhi, 1988).

Perspektif ini memberikan suatu bukti betapa Gandhi mempunyai landasan filosofis dalam meneguhkan ajarannya bahwa semua manusia bersaudara. Sebagai saudara, maka manusia tidak diperbolehkan untuk hidup saling menghancurkan, menghina dan membuat manusia lain sengsara. Realitas ini oleh Gandhi dikatakan: "Manusia adalah mahluk sosial, tanpa keterkaitan dengan masyarakattidak mungkin akan disadarinya persatuan dengan seluruh alam semesta dan tidak mungkin ditindasnya nafsu kepentingan sendiri. Sekalipun di dalam alam cukup terdapat daya tolak, tetapi alam itu hidup berkat adanya rasa timbal balik. Manusia bukan hidup karena penghancuran. Rasa cinta diri mendorongnya untuk mementingkan orang lain pula. Bangsa-bangsa hidup rukun karena terdapat saling mengindahkan dikalangan warganya". (Gandhi, 1988).

Dalam konteks ini, Gandhi mengajukan dua ajaran sebagai penguat bahwa semua manusia adalah bersaudara; yaitu penolakan terhadap penghancuran orang lain dan kehidupan yang mementingkan orang lain. Ajaran ini bagi Gandhi akan menuntun setiap umat manusia untuk menjadikan orang lain sebagai saudara, bukan musuh. Bentuk persaudaraan tersebut sekaligus mengandaikan suatu kenyataan penghilangan setiap bentuk kekerasan, baik fisik maupun psikis dalam masyarakat. Semua manusia bersaudara merepresentasikan suatu bentuk masyarakat damai melalui peniadaan kekerasan.

\section{Bangunan Dasar Masyarakat Tanpa Kekerasan}

Masyarakat tanpa kekerasan merupakan cerminan dari model masyarakat yang diimpikan oleh Gandhi. Gandhi adalah seorang pemikir yang dapat dimasukkan dalam kategori penganut sosialisme utopis, karena ia membayangkan terbentuknya komunitas teladan yang ia contohkan dengan pembentukan ashram. Sebagaimana diketahui terdapat berbagai prinsip etis yang oleh Gandhi digunakan sebagai ajaran moral bagi warga untuk menciptakan prototype masyarakat sebagaimana yang ia inginkan, yaitu masyarakat damai yang nir-kekerasan. Kekerasan hanya akan menimbulkan kesengsaraan bagi umat manusia dan penderitaan yang berlebihan. Hal ini dapat dibuktikan dengan penderitaan warga India 


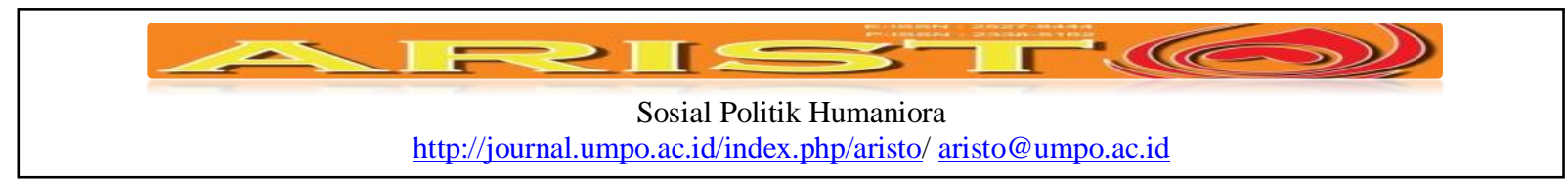

akibat kekejaman perang serta penderitaan orang miskin akibat keserakahan segelintir masyarakat.

Pembentukan masyarakat tanpa kekerasan bagi Gandhi hanya dapat ditemukan melalui komitmen warganya untuk menjalankan ahimsa dan satyagraha. Keduanya merupakan dua kata kembar yang melandasi perjuangan pantang kekerasan Gandhi. Ahimsa adalah falsafah pantang kekerasan yang dikembangkannya, dan satyagraha adalah aksi perjuangan yang tidak memakai kekerasan.Ahimsa dan satyagraha menjadi basis dasar pembentukan masyarakat tanpa kekerasan; ahimsa adalah falsafahnya dan satyagraha adalah perjuangannya. (Thomas Merton, 1988)

Masyarakat yang mengamalkan kedua basis ini akan bergerak menuju komunitas yang emoh kekerasan. Basis tersebut menjadi kekuatan bagi umat manusia untuk menyelenggarakan masyarakat yang terhindar dari penghancuran manusia, termasuk nilai kemanusiaan. Gandhi mengatakan; "Kekuatan yang paling hebat tersedia bagi umat manusia adalah emoh kekerasan. Kekuatan ini lebih ampuh dari senjata pemusnah yang terampuh yang dirancang oleh kecerdikan manusia. Pemusnahan bukanlah hukum bagi manusia. Manusia bisa hidup merdeka hanya dengan kesiapannya untuk mati, bila perlu oleh saudaranya sendiri dan tidak pernah dengan membunuhnya. Setiap pembunuhan dan bentuk penganiayaan lain tak peduli apa penyebabnya yang dilakukan oleh atau ditujukan kepada orang lain adalah suatu tindakan kejahatan terhadap kemanusiaan”. (Gandhi, 1966).

Inti dari bangunan dasar masyarakat tanpa kekerasan tersebut adalah penghargaan atas martabat kemanusiaan. Penghargaan terhadap nilai kemanusiaan menjadi ukuran bagi terciptanya masyarakat yang jauh dari perilaku kekerasan. Semua warga bersama untuk tetap menjadikan nilai kemanusiaan sebagai syarat bagi terbentuknya masyarakat nir-kekerasan. Penguatan sikap moral untuk menjauhi (emoh) kekerasan adalah pilar utama merubah keadaan masyarakat dari himsa menuju ahimsa. "Emoh kekerasan adalah suatu kekuatan aktif yang mulia. Dia adalah kekuataan jiwa dan kekuatan Tuhan dalam diri kita. Manusia yang tidak sempurna tidak bisa menangkap seluruh maknanya.... Kita bisa mendekati sifat Tuhan seimbang dengan kemampuan kita menghayati emoh kekerasan; tetapi kita tak akan pernah menyamai Tuhan. Emoh kekerasan dampaknya bagaikan Radium. Namun setitik Radium itu bisa disusupkan ke dalam tubuh kanker, berdampak terus menerus secara diam-diam tanpa berhenti sampai akhirnya dia berhasil mengubah seluruh bagian yang tertimpa penyakit 


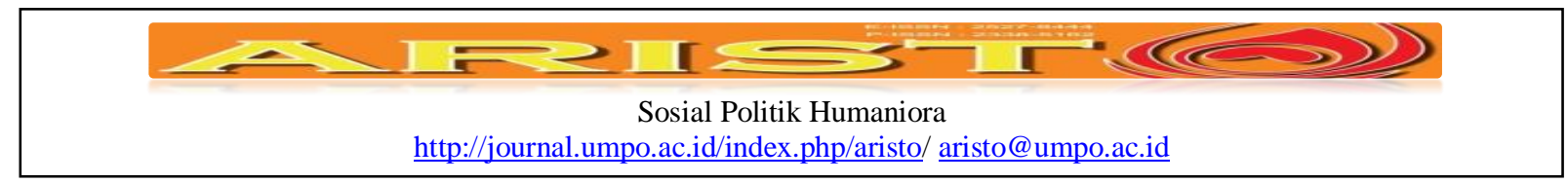

menjadi tubuh yang sehat. Begitu pula secuil emoh kekerasan bereaksi secara diam-diam halus dan tak terlihat namun sanggup mengubah seluruh masyarakat”. (Gandhi, 1978).

Dalam konteks ini, emoh kekerasan yang dipersepsikan Gandhi tidaklah terbatas pada sekat-sekat keagamaan atau status sosial. Emoh kekerasan mengandung nilai universalitas, karena ia dikembangkan ke dalam prinsip kemanusiaan yang bersifat universal. Gandhi mengatakan; "Emoh kekerasan hanya bisa berhasil bila iman kita aktif dan kuat. Buddha, Yesus, dan Muhammad adalah pejuang-pejuang perdamaian dengan caranya masing-masing. Kita harus memperkaya warisan yang ditinggalkan oleh para jagat Guru ini. Tuhan ada caranya sendiri nan-hebat untuk melaksanakan maupun memilih sarananya. Nabi Muhammad dan Abubakar yang terperangkap dalam sebuah goa, diselamatkan dari pengejar mereka oleh laba-laba yang membuat sarangnya menutupi goa itu". (Gandhi, 1996).

Dalam perspektif ini tampak betapa Gandhi tidak pernah mempersoalkan asal-muasal sekat primordialisme yang terintegrasi dalam ajaran tanpa kekerasan. Artinya, pantang kekerasan (ahimsa) dan perjuangan tanpa kekerasan (satyagraha) yang hendak dibentuknya terlahir secara objektif sebagai kebutuhan manusia. Meminjam terminologi Kuntowijoyo objektivikasi adalah penerjemahan nilai-nilai internal dalam agama (misalnya) ke dalam kategori-kategori objektif. Nilai-nilai yang terkandung dalam ahimsa dan satyagraha sebagai basis bangunan masyarakat tanpa kekerasan secara implisit terdapat dalam semua agama dan tradisi, sekaligus merupakan objektivikasi ajaran kebenaran. (Kuntowijoyo. 1997)

Basis penguatan masyarakat tanpa kekerasan tersebut mewujudkan diri ke dalam perilaku masyarakat untuk mengedepankan rasa kasih sayang kepada seluruh umat manusia. Umat manusia sebagai saudara, tanpa permusuhan, tanpa saling membenci serta kemampuan untuk tidak pernah menghadirkan kekerasan di dalamnya menjadi representasi dari kesempurnaan sikap hidup manusia dalam mewujudkan dirinya sebagai mahluk sosial. Nilainilai tersebut jelas merepresentasikan sebuah kebenaran. Kebenaran adalah Tuhan itu sendiri, sehingga wujud kasih sayang sebagai sebuah kebenaran merupakan tempat bersemayamnya Tuhan. Gandhi, berkata: “dimana ada kasih sayang disanalah Tuhan bersemayam”. (Gandhi, 1988)

Persepsi Gandhi yang demikian kuat terbentuk dari pengalaman panjang keperihan dan penderitaan yang dialaminya, serta pula dialami oleh masyarakat korban kekejaman perang. Perang dan kekerasan telah menghadirkan derita berkepanjangan yang implikasi 


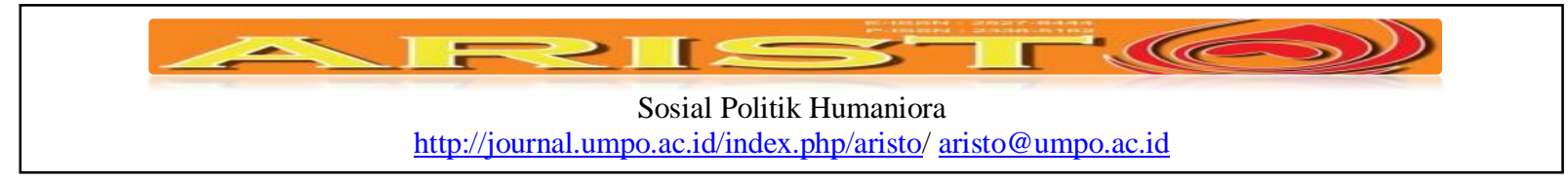

logisnya justru semakin menjebak manusia untuk menguatkan perilaku kekerasan dalam masyarakat. Dalam perang seringkali kekerasan hanya dilawan dengan kekerasan. Perilaku tersebut pada akhirnya hanya membentuk - meminjam terminologi Dom Camara sebagai spiral of violence (spiral kekerasan). Kekerasan yang dilawan dengan kekerasan hanya akan melahirkan kekerasan terus menerus dan itu yang disaksikan oleh Gandhi dalam perjalanan hidupnya baik di Afrika Selatan maupun di India. (Dom Camara. 1971)

Realitas tersebut membulatkan tekadnya untuk melakukan perjuangan satyagraha (Gandhi, 2001). Menurut Gandhi memulai langkahnya dengan menerapkan pola kehidupan ahimsa (falsafah pantang kekerasan) kepada warga untuk menjadi semangat dalam menjalankan perjuangannya. Dia mengatakan bahwa: " tidaklah mungkin sebuah perjuangan terhindar dari perilaku kekerasan, tatkala falsafah hidupnya tidak digerakkan oleh basis sikap perilaku yang juga menghindarkan diri dari kekerasan”. Artinya, falsafah hidup dapat berpengaruh secara massif ke dalam perilaku kongkrit masyarakat. Falsafah hidup menggerakkan manusia untuk menentukan sikap dan tindakannya. Itulah sebabnya Gandhi berkeyakinan bahwa falsafah hidup pantang kekerasan (ahimsa) harus merupakan landasan bagi setiap bentuk perjuangan melawan penindasan dan kesewenang-wenangan. Kekerasan tidak boleh dilawan dengan kekerasan. Kekerasan dilawan dengan kekerasan hanya akan memunculkan reproduksi kekerasan atau kekerasan jenis baru. (Gandhi.1988)

Gandi menjelaskan pantang kekerasan dan gerakan tanpa kekerasan merupakan suatu kebaikan yang universal. Kedua basis tersebut bukan semata-mata sebagai suatu taktik politik dalam upayanya membebaskan rakyatnya dari kekuatan asing, namun semangat tersebut lahir dari suatu kesadaran batin tentang kesatuan spiritual dalam dirinya sendiri. (Gandhi. 1988) Thomas Merton memberikan penjelasan tentang keseluruhan konsep ajaran Gandhi yakni aksi pantang kekerasan dan satyagraha tidak akan dapat dipahami apabila dipikirkan sebagai suatu cara untuk mencapai persatuan serta bukan sebagai buah persatuan batin yang tercapai terlebih dahulu. (Thomas Merton. 1992)

Melalui gerakan yang dilakukan oleh Gandhi, ahimsa dan satyagraha, ia berusaha mewujudkan tiga macam pembebasan; Pertama, ia ingin melepaskan kebijaksanaan religius India dari kebutaan dan kemerosotan yang sedang dialami.Kebijaksanaan religius India sebagai akibat ketidakadilan yang keterlaluan dari suatu sistem yang sudah menyalahi sifatnya sendiri yang sebenarnya. Kedua, ia ingin membebaskan kaum hina dina 'Harijan', bukan 


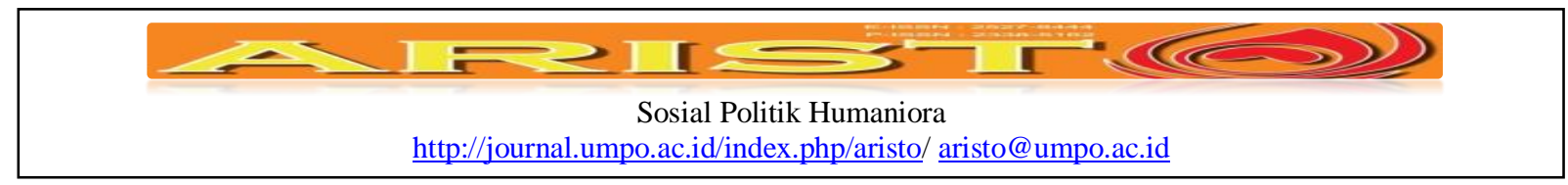

hanya dari penindasan politik dan ekonomi melainkan juga dari mimpi buruk mereka yaitu kebencian diri serta keputusasaan mereka, dan Ketiga, Gandhi berkeinginan membebaskan para penindas sendiri dari ketergantungan mereka secara membabibuta dan tanpa harapan pada sistem yang mempertahankan keadaan seperti apa adanya. Ketiga upaya tersebut menunjukkan semangat Gandhi dari upaya untuk melakukan liberalisasi (pembebasan) umat manusia dari situasi-situasi yang bersifat sub-human. Yang bertidak kekerasan sekaligus yang tertimpa kekerasan pada dasarnya berada dalam derajat sub-human tersebut.

Thomas Merton memaparkan yang menarik dalam konsepsi Gandhi tersebut adalah keluasannya, keterpaduannya dan kesatuannya. Gandhi telah memberikan ajaran sekaligus warisan kepada dunia bahwa kejahatan yang diderita umat manusia tidak dapat dibinasakan dengan serangan kekerasan, yakni satu bagian umat manusia menyerbu bagian yang lain dengan kemurkaan yang menghancurkan. Kejahatan yang terjadi pada umat manusia dalam masyarakat adalah kejahatan bersama dan pemecahannya-pun harus pemecahan bersama. (Thomas Merton. 1992)

Perubahan masyarakat dengan demikian harus diawali terbentuknya pribadi luhur manusia penyusunnya. Sebagaimana dikatakan Gandhi bahwa tidak mungkin ada perdamaian di dunia tanpa jenis perubahan batin yang memulihkan manusia pada 'hati-nurani'-nya. (Gandhi. 1982) namun dmeikian bagi Gandhi ahimsa (pantang kekerasan) merupakan hukum dasar bagi hidup manusia. Itulah sebabnya mengapa ahimsa dapat digunakan sebagai prinsip paling efektif untuk tindakan sosial, karena secara mendalam sesuai dengan kebenaran sifat alami manusia dan sesuai benar dengan keinginan bawaannya akan perdamaian, keadilan, ketertiban, kebebasan dan martabat pribadi. Oleh karena himsa (kekerasan) merendahkan dan merusak manusia, maka menghadapi kekerasan dengan kekerasan, dan kebencian dengan kebencian hanya akan menambah parahnya kemerosotan secara progresif dari manusia. Sedangkan pantang kekerasan kebalikannya, menyembuhkan dan memulihkan sifat alami manusia sembari memberikan kepadanya sarana bagi penyembuhan serta pemugaran ketertiban dan keadilan sosial. Ahimsa bukan suatu kebijakan untuk merebut kekuasaan. Ahimsa merupakan jalan untuk mengubah hubungan-hubungan agar terlaksana peralihan kekuasaan secara damai, dilakukan dengan sukarela tanpa desakan oleh semua yang bersangkutan. Oleh karena semua mengakuinya sebagai hak. (Gandhi. 1988) 


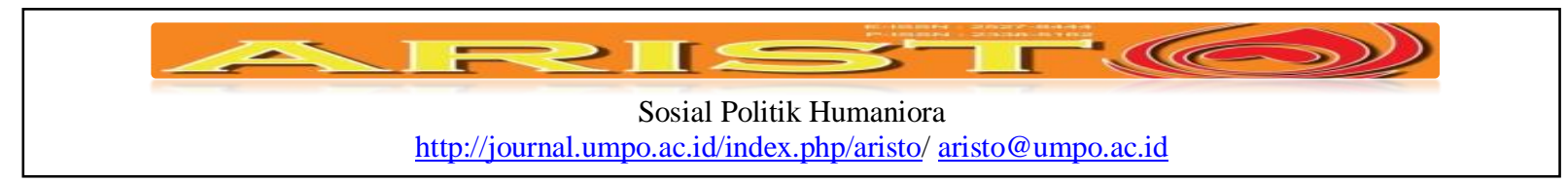

Pantang kekerasan bagi Gandhi adalah kekuasaan yang dapat membentuk masyarakat. Kedamaian dan ketertiban dalam masyarakat hanya dapat terwujud bila antara individu penyusunnya mempunyai kesadaran penuh untuk melaksanakan prinsip pantang kekerasan. "Pantang kekerasanmencakup pemurnian diri yang sesempurna mungkin bagi manusia. Bagi perorangan, kekuatan pantang kekerasan adalah dalam proporsi yang tepat sesuai dengan kemampuan, bukan kamauan, dari pengamat pantang kekerasan untuk menimbulkan kekerasan. Kekuatan yang tersedia bagi penganut pantang kekerasan selalu lebih besar daripada jika ia bersifat keras. Tidak ada kekalahan dalam pantang kekerasan. Ahimsa (pantang kekerasan) adalah satu-satunya kekuatan yang sejati dalam hidup. Ahimsa adalah satu-satunya hal yang permanen dalam hidup, satu-satunya mengandung arti, usaha apapun yang engkau limpahkan baginya adalah berguna sebaik-baiknya". (Gandhi, 1972).

Konsepsi masyarakat tanpa kekerasan yang dikonstatir Gandhi tersebut di atas mempunyai ciri khas. Hal tersebut dapat ditemukan dari bentuk-bentuk kekuatan yang menyusun bangunan dasar bagi masyarakat tersebut yang lebih bersifat spiritual daripada material. Spiritual dalam artian bahwa basis dasar masyarakat yang hendak dikembangkan oleh Gandhi berhubungan dengan aspek kerohanian manusia bukan aspek fisik dari kodrat kemanusiaan.

Konskuensi logis dari penerapan ahimsa dalam pembentukan masyarakat tanpa kekerasan tersebut adalah diberlakukannya gerakan satyagraha atau perjuangan tanpa melibatkan unsur-unsur kekerasan. Gandi memaparkan secara detail jika satyagraha selalu lebih unggul dari perlawanan bersenjata. Untuk dapat mencapai tujuan dalam satyagraha, Gandhi selanjutnya memberikan tiga syarat; pertama, sang satyagrahi harus tidak mempunyai rasa benci kepada lawan; kedua, urusannya harus benar dan penting; ketiga, sang satyagrahi harus bersedia menderita sampai akhir. Muara dari semuanya adalah bahwa manusia dalam sosialitas harus memainkan hidup dengan cinta kasih antara sesama. Hanya dengan cinta kasih hidup menjadi bermakna, dan hanya melalui cinta kasih, satyagraha dapat diwujudkan. (Gandhi, 1972).

\section{Implikasi Pemikiran Gandhi Terhadap Pembentukan Masyarakat Sipil di Indonesia}

Sejak belakangan ini tema tentang masyarakat sipil di Indonesia mulai menunjukkan bentuknya. Hampir setiap saat ditemukan berbagai perdebatan panjang perihal konsepsi 


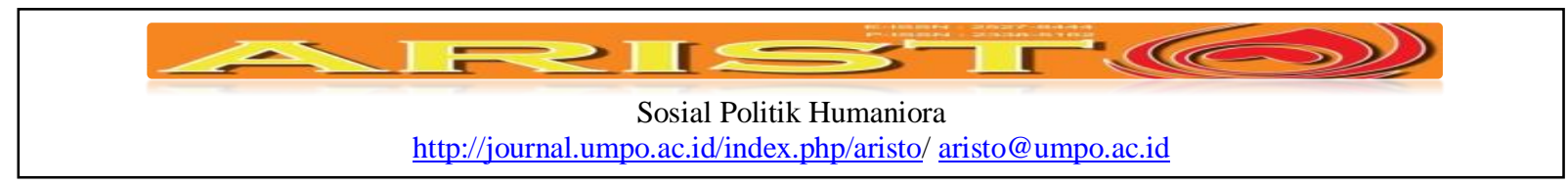

masyarakat sipil yang cocok diterapkan di Indonesia, yang realitas masyarakatnya beragam dan multi-etnik. Realitas masyarakat yang demikian seringkali menyulitkan bagi terciptanya masyarakat sipil yang dicita-citakan. Apalagi, kenyataan menyebutkan betapa kemajemukan atau pluralitas tidak hanya menjadi kekuatan untuk mempersatukan (uniting factor), melainkan juga dapat berfungsi sebagai faktor pemecah belah (deviding factor). Berbagai konflik dan kekerasan yang muncul belakangan ini merepresentasikan betapa masih sulitnya keinginan untuk menciptakan masyarakat sipil yang dicita-citakan, yaitu masyarakat sipil yang mandiri, otonom dan jauh dari perilaku kekerasan.

Berdasarkan fenomena kekerasan dan konflik yangterjadi di Indonesia, maka ajaran prinsip-prinsip etis yang dikembangkan Gandhi dalam ashram serta keyakinannya bahwa 'semua manusia bersaudara' menemukan titik relevansinya. Sebagaimana diketahui, salah satu tema penting yang mengedepan dalam diskursus pemikiran di Indonesia belakangan ini adalah menguatkan ide tentang masyarakat sipil. Setelah lama hidup dalam bayang-bayang otoritarinisme kekuasaan negara pada massa Orde Baru, masyarakat Indonesia seolah terlepas dari kekuasaan yang hegomoni tersebut.

Antonio Gramsci menjelaskan bahwa kekuasaan yang bersifat hegomonik selalu mematikan potensi-potensi penguatan masyarakat sipil. Berakhirnya kekuasaan yang hegomonik semasa Orde Baru memberikan inspirasi dan semangat baru bagi munculnya ideide penguatan masyarakat sipil. Artinya, selama ini negara menguasai hampir keseluruhan sendi-sendi kehidupan masyarakat, sehingga ruang-ruang 'rakyat' yang secara kultural tumbuh subur dalam masyarakat menjadi tidak berkembang atau sengaja dimatikan. Akibatnya, masyarakat menjadi tergantung secara berlebihan pada negara. Implikasi logisnya, ketika negara dalam keadaan tidak stabil atau mengalami kemunduran peran, maka situasi masyarakat berada dalam kondisi yang chaos (kacau). Fenomena merebaknya konflik dan disintegrasi bangsa di berbagai belahan daerah merepresentasikan suatu bukti terjadinya ketidakmampuan masyarakat dalam mengelola kepentingan dan perbedaan yang berkembang. (Antonio Gramsci. 1991)

Menurut Umar Kayam Implikasi logisnya adalah situasi anarki atau pemecahan masalah dengan kekerasan telah menjadi satu-satunya jalan bagi masyarakat. Realitas ini membuktikan terjadinya situasi paradoks dalam perubahan masyarakat di Indonesia pascareformasi nasional. Di satu sisi menginginkan terjadinya penguatan masyarakat sipil yang 


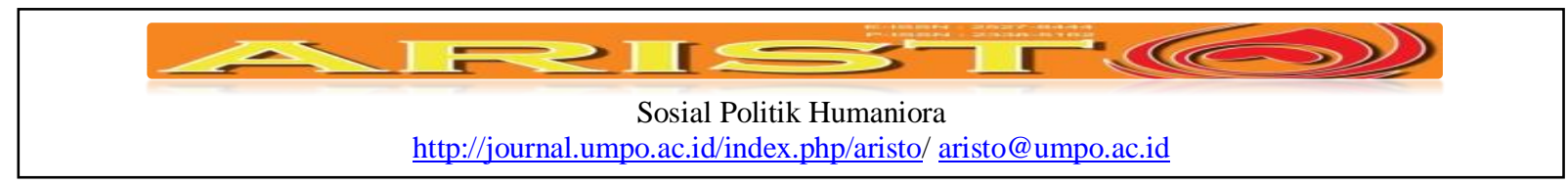

mandiri, lepas dari intervensi negara, tetapi di sisi lain justru melahirkan fenomena konfliktual yang semakin terakumulasi. Padahal basis dasar dari masyarakat sipil adalah kemampuan untuk mengelola perbedaan dan persoalan melalui kultur masyarakat dialog. Kultur masyarakat dialog mencerminkan kekuatan untuk menghormati kepentingan yang berbeda dan penyelesaiannya juga harus meminimalkan terjadinya konflik antar kelompok. (Tim Maulana, 1999)

Basis masyarakat sipil yang seharusnya dikembangkan di Indonesia adalah penguatan masyarakat yang mengedepankan; (1) dialog dalam menyelesaikan masalah, (2) menjauhkan diri dari perilaku konfliktual dankekerasan, (3) mengedepankan kepentingan bersama atas dasar nilai-nilai kemanusiaan, dan (4) mempunyai kemandirian dalam segala bidang, sosial, politik dan ekonomi. Kemandirian dalam konteks ini adalah kemampuan untuk menyelesaikan masalah sendiri tanpa keterlibatan kekuatan lain, termasuk negara. Kemandirian di bidang ekonomi misalnya, menunjukkan satu sisi kekuatan dari masyarakat sipil untuk dapat memenuhi kebutuhan mereka sendiri. (AS. Hikam, 1999)

Prinsip-prinsip yang demikian menunjukkan relevansinya dengan ajaran Gandhi yang terdapat dalam 11 prinsip etik yang harus dipatuhi oleh warga ashram. Kesebelas prinsip etik tersebut merupakan kekuatan untuk mewujudkan kemandirian secara penuh dalam masyarakat dari berbagai bentuk hegomoni dan intervensi oleh kekuatan manapun. Melalui penerapan ajaran Gandhi, maka dapat diciptakan suatu komunitas teladan yang dalam konteks ini minimal dinamakan sebagai civil society (masyarakat sipil). Menurut Umar Kayam salah satu yang memberikan dasar bagi perlunya ide-ide penguatan masyarakat sipil adalah pentingnya prinsip harmoni sosial, yang mengandung pengertian untuk tidak menciptakan situasi chaos (kekacauan) yang dapat merusak hubungan antar manusia. (Tim Maulana, 1999)

Masyarakat sipil dalam hal ini pada dasarnya merupakan suatu model masyarakat yang tercipta berkat partisipasi yang penuh kebebasan oleh sejumlah manusia yang masing-masing dalam kedudukan yang berkesamaan derajat, berkomitmen untuk membangun bersama suatu komunitas politik yang disebut Negara, Dalam kehidupan modern yang penuh dengan citacita pembebasan manusia dari segala bentuk penindasan dan ketertindasan, maka pembentukan masyarakat sipil merupakan realitas yang harus dikedepankan. (Soetandyo Widnjosoebroto, 1999). 


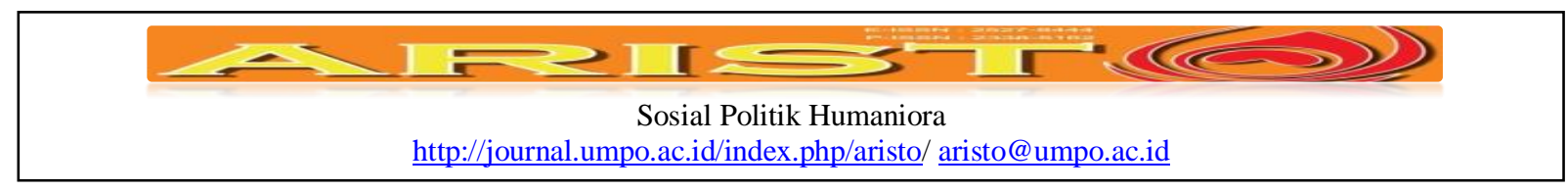

Masyarakat sipil yang demikian adalah realitas hilangnya bentuk penindasan sekaligus ketertindasan dari manusia. Pembentukan masyarakat sipil merupakan keniscayaan untuk menghilangkan berbagai bentuk kekerasan sekaligus perilaku yang mengedepankan kekerasan di dalamnya. Prinsip dasar yang hendak dibangun dalam konsep masyarakat sipil pada dasarnya adalah pengarus-utamaan tema-tema kepentingan bersama di atas, kepentingan sendiri berdasarkan pada nilai-nilai kemanusiaan sebagai nilai yang bersifat universal. Prinsip ini dalam banyak hal diyakini oleh Gandhi sebagai moralitas bersama yang harus dianut dan dijalankan oleh setiap warga agar kehidupan umat manusia tidak dilandasi oleh nafsu untuk menguasai orang lain. Sebagaimana pernah diyakini Gandhi bahwa 'semua manusia bersaudara', sehingga setiap manusia harus menghormati orang lain atas dasar kemanusiaan sebagai nilai yang berlaku secara universal.

\section{Kesimpulan}

Secara eksplisit Gandhi tidak pernah memberi batasan dan pemahaman mengenai masyarakat. Pemahamannya tentang masyarakat selalu terintegrasi dengan gagasan-gagasan besarnya tentang perlunya tatanan dalam masyarakat yang harmonis dan terhindar dari prilaku konfliktual. Namun demikian, Gandhi adalah seorang yang konsisten memegang pendirian dan keteguhan hati untuk membangun komunitas yang mengedepankan harmoni sosial, maka ia selalu berusaha menampilkan suatu konsepsi tentang konstruksi masyarakat dan bukan pengertian masyarakat.

Konstruksi masyarakat yang diinginkan Gandhi adalah masyarakat nir-kekerasan (non violence), hal ini memungkinkan dicapai hanya melalui komitmen warganya untuk menjalankan prinsip ahimsa dan satyagraha. Ahimsa adalah falsafah pantang kekerasan dan satyagraha adalah aksi perjuangan yang tidak mengenal kekerasan. Hal ini dicoba diterapkan Gandhi pada ashram, yang kemudian warga ashram menjadi komunitas tauladan yang diidamkan.

Mencermati fenomena kekerasan dan konfliktual yang terjadi di Indonesia, maka prinsipprinsip etis masyarakat yang dikembangkan Gandhi dalam ashram serta keyakinannya bahwa 'sетиа manusia bersaudara', menjadi menemukan titik relevansinya bagi masyarakat Indonesia yang menginginkan terbentuknya masyarakat sipil (civil society). Prinsip dasar yang hendak dibangun dalam masyarakat sipil adalah pengarus-utamaan tema-tema kepentingan bersama dan kepentingan individu pada nilai-nilai kemanusiaan yang universal. 


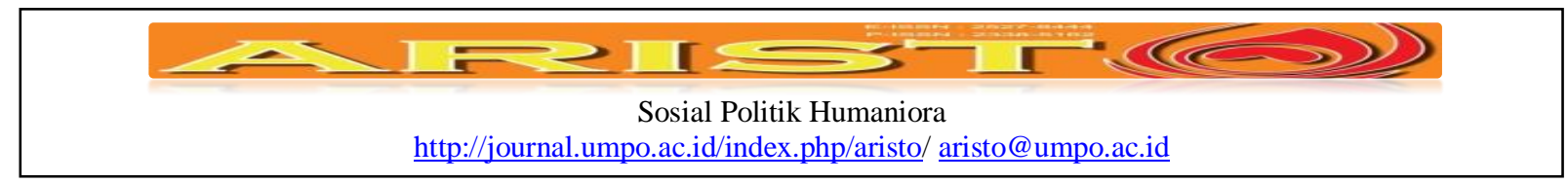

\section{Daftar Pustaka}

Andrews, C.F., 1949. Mahatma Gandhi Ideas. George Alen dan Unwin Ltd: London.

Bakker, A. dan A. Charis Zubair, 1990. Metodologi Penelitian Filsafat. Kanisius: Yogyakarta.

Gandhi, M.K., 1959. Ashram Observances Action. Navajivan Publishing House: Ahmedabad.

Gandhi, M.K.,1981. Ashram Observance in Action. terj. Gedong Bagoes Oka. Yayasan Bali Santi Sena: Bali.

Gandhi, M.K., 1978. A Story of My Experiments with Truth. terj. Gd. Bagoes Oka. Yayasan Bali Santi Sena: Denpasar.

Gandhi, M.K., 1979. From Yeravda Mandir. terj. Gedong Bagoes Oka. Yayasan Bali santi Sena: Bali.

Gandhi, M.K.,1982. Gandhi Sebuah Otobiografi, Kisah Ekspremen-Ekspremenku Dalam Mencari Kebenaran. terj. Gedong Bagoes Oka. Sinar Harapan: Jakarta.

Gandhi, M.K., 1950. Religi Susila. terj. Sumirat. Balai Pustaka: Jakarta.

Gandhi, M.K., 1951. Satyagraha. Navajivan Publishing House: Ahmedabad.

Gandhi, M.K., 1958. Satyagraha (ed. Bharatan Kamurappa). Navajivan Publishing House: Ahmedabad.

Gandhi, M.K., 1988. Semua Manusia Bersaudara, Kehidupan dan Gagasan Mahatma Gandhi Sebagaimana Diceritakannya Sendiri. terj. Kustiniyati Mochtar; kata pengantar Mochtar Lubis. Obor dan Gramedia: Jakarta.

Gandhi, M.K., 1953. Toward New Education. Navajivan Publishing House: Ahmedabad.

Gandhi, M.K., 1982. Tuhanku (oh My Gandhi). Ashram Gandhi: Bali.

Gramsci, Antonio, 1991. Selections from Prison Notebooks. Lawrence \& Wishat: London.

Hikam, Moh. AS., 1999. Politik Kewarganegaraan. PT. Rosdakarya: Bandung.

Sugiharta, I. P. S. O., \& Sudarsana, I. K. (2017). Hypnotic Learning Characteristics On Sisya Brahmakunta Community In Denpasar. Vidyottama Sanatana: International Journal of Hindu Science and Religious Studies, 1(2), 132-145.

Kayam, Umar, 1999. "Menghidupkan Kultur Masyarakat Berembuk", dalam Tim MAULANA, editor 1999. Jika Rakyat Berkuasa. Pustaka Hidayah:Bandung.

Kuntowijoyo, 1997. Identitas Politik Umat Islam. Mizan: Bandung. 


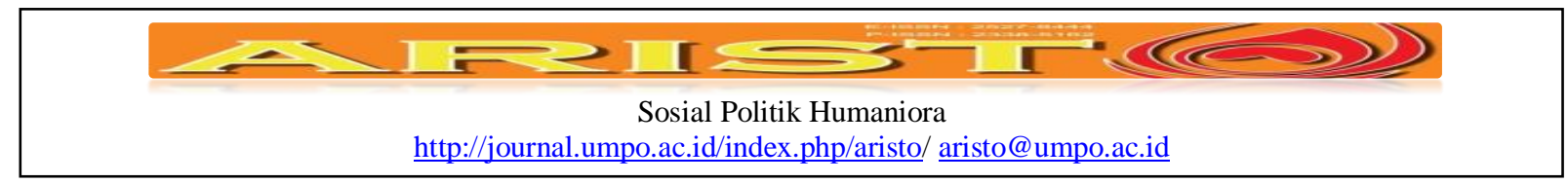

Lubis, Mochtar, 1988. Menggapai Dunia Damai. Yayasan Obor Indonesia: Jakarta.

Mehta, Ved, 2002. Ajaran-Ajaran Mahatma Gandhi, Kesaksian dari Para Pengikut dan Musuhmusuhnya, terj. Siti Farida. Pustaka Pelajar: Yogyakarta.

Merton, Thomas, 1992. Gandhi tentang Pantang Kekerasan. Yayasan Obor Indonesia: Jakarta.

Nicholson, Michael, 1994. Mahatma Gandhi, Pahlawan yang Membebaskan India dan Memimpin Dunia dalam Perubahan Tanpa Kekerasan. terj. Hilman Farid Seiadi. Gramedia Pustaka Utama: Jakarta.

Pleyser, 1992. Gandhi Pelopor Kemerdekaan India. Jambatan: Yogyakarta.

Richards, Glyn, 1982. The Filosophy of Gandhi, A Study of his basic ideas. Curzon Press, Barnes \& Noble Books: London.

Sudarsana, I. K. (2016). Pemikiran tokoh pendidikan dalam buku lifelong learning: policies, practices, and programs (Perspektif Peningkatan Mutu Pendidikan di Indonesia). Jurnal Penjaminan Mutu, 2(2), 44-53.

Sen, Ela, 1948. Gandhi Biographical Study. Valian Publications Ltd.: London.

Thekkenedath, J., 1978. Love of Neighbour in Mahatma Gandhi. St. Paul's Press Trainning School: Bangalore.

Veeger, K.J., 1993. Realitas Sosial, Refleksi Filsafat Sosial atas Hubungan Individu-Masyarakat dalam Cakrawala Sejarah Sosiologi. Gramedia Pustaka Utama: Jakarta.

Wakefield, Gordon S., 1986. Dictionary of Cristian Spirituality. SCM Press: London.

Wegig, R. Wahana, 1986. Dimensi Etis Ajaran Gandhi. Kanisius: Yogyakarta.

Wibowo, Toto Wasis, 1989. Ajaran Gandhi tentang Ashram (Suatu Studi Sosiologis Mengenai Toleransi Umat Beragama). Skripsi S1, Fakultas Ushuluddin IAIN Sunan Kalijaga: Yogyakarta.

Widnjosoebroto, Soetandyo, 1999. "Masyarakat Warga: Prasyarat Terwujudnya Kehidupan Demokratis dalam Bernegara" dalam Tim MAULA, 1999. Jika Rakyat Berkuasa. Pustaka Hidayah: Bandung.

Wisarja, I. K., \& Sudarsana, I. K. (2017). REFLEKSI KRITIS IDEOLOGI PENDIDIKAN KONSERVATISME DAN LIBRALISME MENUJU PARADIGMA BARU PENDIDIKAN. Journal of Education Research and Evaluation, 1(4), 283-291. 


Sosial Politik Humaniora
http://journal.umpo.ac.id/index.php/aristo/ aristo@umpo.ac.id

Wisarja, I. K., \& Sudarsana, I. K. (2017). Praksis Pendidikan Menurut Habermas (Rekonstruksi Teori Evolusi Sosial Melalui Proses Belajar Masyarakat). Indonesian Journal of Educational Research, 2(1), 18-26.

Wisarja, I. K., \& Sudarsana, I. K. (2017). REFLEKSI KRITIS IDEOLOGI PENDIDIKAN KONSERVATISME DAN LIBRALISME MENUJU PARADIGMA BARU PENDIDIKAN. Journal of Education Research and Evaluation, 1(4), 283-291. 